\title{
KEMAMPUAN BERPIKIR LATERAL DALAM MEMECAHKAN MASALAH FISIKA
}

\section{THE ABILITY TO THINK LATERALLY IN SOLVING PHYSICS PROBLEMS}

\author{
${ }^{1)}$ M. Agus Martawijaya, ${ }^{2)}$ Jayanti Jabir, ${ }^{3)}$ Aisyah Azis \\ Universitas Negeri Makassar \\ Kampus UNM Parangtambung Jln. Daeng Tata Raya, Makassar, 90224 \\ ${ }^{1)}$ e-mail : jayantijabir51@gmail.com
}

\begin{abstract}
The Ability To Think Laterally In Solving Physics Problems. This research is descriptive qualitative research that aims to determine the ability of students to think laterally in solving physics problems. The subjects in this study were students of class XI MAN Luwu, as many as 8 students. To see the students' lateral thinking skills, researchers used physics-based test instruments. The technique of data collection carried out in this study is to carry out tests to see the answers of students then conduct interviews to explore further information in order to find out the thinking process of students. The collected data is then analyzed by reducing and displaying data to produce lateral thinking patterns that are presented in the form of a chart. The indicators that are references to lateral thinking are if there are changes in concepts or perceptions of students about the problem given. So it can be concluded that students have been able to think laterally in solving physics problems. The suggestion put forward by researchers is the need to provide physical questions that are lateral to students to stimulate their thinking processes
\end{abstract}

Keywords : Physics, Ability, Lateral Thinking, Physics Problem.

\begin{abstract}
Abstrak. Kemampuan Berpikir Lateral Dalam Memecahkan Masalah Fisika. Penelitian ini adalah penelitian kualitatif deskriptif yang bertujuan untuk mengetahui kemampuan berpikir lateral peserta didik dalam memecahkan masalah fisika. Subjek dalam penelitian ini adalah peserta didik kelas XI MAN Luwu, sebanyak 8 peserta didik. Untuk melihat kemampuan berpikir lateral peserta didik peneliti menggunakan instrumen tes berbasis masalah fisika. Tehnik pengumpulan data yang dilakukan dalam penelitian ini adalah melakukan tes untuk melihat jawaban peserta didik kemudian melakukan wawancara untuk menggali informasi lebih lanjut guna mengetahui proses berpikir peserta didik. Data yang telah terkumpul kemudian dilakukan analisis dengan mereduksi dan mendisplay data sehingga menghasilkan pola berpikir lateral yang disajikan dalam bentuk bagan. Adapun indikator yang menjadi acuan berpikir lateral adalah apabila ada perubahan konsep atau persepsi peserta didik terhadap masalah yang diberikan. Sehingga dapat disimpulkan bahwa peserta didik sudah mampu berpikir lateral dalam memecahkan masalah fisika. Adapun saran yang diajukan peneliti adalah perlunya untuk memberikan soal-soal fisika bersifat lateral kepada peserta didik untuk merangsang proses berpikirnya.
\end{abstract}

Kata kunci : Fisika, Kemampuan, Berpikir Lateral, Masalah Fisika

\section{PENDAHULUAN}

Pendidikan adalah upaya manusia untuk memanusiakan manusia, mengingat sasaran pendidikan yaitu manusia. Pendidikan bertujuan mengembangkan kemampuan dan potensi manusia sehingga dapat hidup layak, baik sebagai pribadi maupun sebagai anggota masyarakat dan diharapkan mampu menghasilkan SDM berkemauan dan berkemampuan untuk senantiasa meningkatkan kualitas secara terus menerus dan berkesinambungan.

Pendidikan bermaksud membantu peserta didik untuk menumbuh kembangkan potensi yang ada dalam dirinya. Pendidikan juga merupakan kebutuhan utama manusia untuk meningkatkan taraf kehidupannya. Apalagi dengan kemunculan suatu gagasan yang mengatakan bahwa generasi emas produktif 2045 yang menyiapkan generasi muda yang tidak hanya sebagai pengguna tetapi juga sebagai pencipta maka dari itu pendidikan memegang peran yang sangat penting.

Menurut Peraturan Menteri Pendididikan Nasional (Permendiknas) No 22 tahun 2006 tentang standar isi mata pelajaran Fisika menyebutkan bahwa mata pelajaran Fisika 
bertujuan agar peserta didik memiliki kemampuan mengembangkan kemampuan bernalar dalam berpikir analisis induktif dan deduktif dengan menggunakan konsep dan prinsip fisika untuk menjelaskan berbagai peristiwa alam dan menyelesaikan masalah baik secara kualitatif maupun kuantatif ${ }^{1}$.

Edwar De Bono (2009:45) menuliskan. "the word 'lateral' in relation to thinking means moving across patterns instead of moving along them that is the nature and the logic of creativity". Berpikir lateral adalah memecahkan masalah melalui pendekatan langsung dan pendekatan kreatif, dengan menggunakan penalaran dan melibatkan dan ide-ide yang mungkin tidak diperoleh dengan hanya menggunakan langkah demi langkah pola traditional. Berpikir lateral merubah cara dari tradisi tradisional, bekerja untuk persepsi-persepsi baru pada objek yang sama serta mencoba menangani masalah pembelajaran dari beberapa arah dan sudut pandang beragam sehingga melahirkan potensi yang lebih baik dalam kreativitas.

Kemampuan untuk memberi gagasangagasan baru yang dapat diterapkan dalam pemecahan masalah atau sebagai kemampuan untuk melihat hubungan-hubungan baru antara unsur-unsur yang sudah ada sebelumnya. Dengan berpikir lateral ini peserta didik akan mampu mengembangkan langkah-langkah pemecahan masalah yang dihadapinya, spesifikasinya adalah penyelesaian soal ujian.

Mengingat setiap peserta memiliki cara berpikir yang berbeda, maka kemungkinan peserta didik akan memberikan tanggapan yang berbeda pula ketika di berikan sebuah masalah yang berkaitan dengan fisika.

Jika peserta didik selalu diberikan masalah maka diharapkan kemampuan untuk berpikir lateral semakin berkembang.

Dari urian di atas, maka peneliti tertarik untuk mengkaji lebih dalam tentang kemampuan berpikir lateral. oleh karena itu judul dari penelitian yang dipilih adalah " Kemampuan berpikir lateral peserta didik dalam menyelesaikan masalah fisika di MAN Luwu".

\section{METODE}

Penelitian ini merupakan penelitian kualitatif yang menggunakan metodologi penelitian dekriptif. Menurut Sugiyono (2013:1) metode penelitian kualitatif adalah metode penelitian yang digunakan untuk meneliti pada kondisi obyek yang alamiah, (sebagai lawannya adalah eksperimen) dimana peneliti adalah sebagai instrumen kunci. Hal yang dideskripsikan dalam penelitian ini adalah proses kemampuan berpikir lateral peserta didik ketika menyelesaikan masalah fisika. Pendeskripsian ini ditelusuri melalui pengamatan langsung dalam proses wawancara secara mendalam.

Penelitian ini bertujuan untuk mengetahui kemampuan berpikir lateral peserta didik dalam memecahkan masalah fisika. Ungkapan-ungkapan yang disampaikan berupa kata-kata, maka penelitian ini bersifat kualitatif yang di kategorikan dalam penelitian kualitatifdeskriptif.

Adapun yang menjadi sumber data dalam penelitian ini adalah kelas XI MIA MAN Luwu. Seluruh peserta didik kelas XI MIA yang berjumlah 87 orang merupakan sasaran dalam penelitian ini. Selanjutnya dari ke-3 kelas MIA tersebut akan dipilih beberapa peserta didik sebagai subjek penelitian. Peserta didik yang menjadi subjek penelitian dari yang memiliki nilai-nilai yang tinggi atau peserta didik yang berprestasi yang direkomendasikan oleh guru fisika yang bersangkutan, sehingga di peroleh 8 orang peserta didik yang menjadi subjek penelitian.

Instrumen yang digunakan pada penelitian ini adalah pemberian masalah pemicu sebanyak 8 masalah (lamp B1) dalam bentuk cerita untuk mengetahui kemampuan berpikir lateral peserta didik. Kemudian melakukan 
wawancara kepada setiap subjek penelitian yang diajukan secara lisan dan dijelaskan dengan sedetail mungkin. Setiap gagasan atau jawaban yang dilontarkan oleh responden kemudian disanggah kembali dengan kata "jika tidak bisa" dan "jika tidak ada" hingga peserta didik jenuh atau tidak bisa lagi memberikan jawaban terhadap masalah yang diberikan. Adapun indikator dalam pembuatan instrumen yang digunakan yaitu apabila adanya perubahan persepsi atau konsep pada peserta didik.

Analisis data yang digunakan dalam penelitian ini adalah sebagai berikut.

1. Data kevalidan diperoleh dengan cara menganalisis hasil penilaian 2 (dua) orang ahli terhadap Instrumen dengan menggunakan analisis Gregory.

2. Data reduksi diperoleh dengan memilah-milah data yang telah dikumpulkan hingga mencapai titik jenuh ke dalam suatu konsep tertentu, kategori tertentu, atau tema tertentu.

3. Data display yaitu dalam penelitian kualitatif, penyajian data dilakukan dalam bentuk uraian singkat, dan transkrip wawancara.

4. Penarikan kesimpulan dan verifikasi yaitu berupa temuan baru. Temuan yang dimaksud dapat berupa deskripsi dari suatu objek yang sebelumnya belum begitu jelas sehingga setelah diteliti dapat menjadi jelas. Selain itu, temuan tersebut dapat pula berupa hubungan kausal atau interaktif, hipotesis atau teori. Di akhir penelitian ini kesimpulan berupa deskripsi yang dapat memperjelas mengenai kemampuan peserta didik dalam berpikir lateral.

\section{HASIL DAN PEMBAHASAN}

Hasil penelitian yang diperoleh disajikan dalam bentuk gambar sebagai berikut.

Keterangan: tanda panah ke bawah hitam $(\boldsymbol{\downarrow})=$ belum ada perubahan persepsi

tanda panah ke samping hitam $(\vec{\Rightarrow})=$ adanya perubahan persepsi (mampu berpikir lateral)

tanda panah warna putih $(\Omega \vec{\gamma})=$ berhenti (tidak ada jawaban).

\section{MASALAH 1}

Berikut ini pola jawaban responden untuk masalah 1.

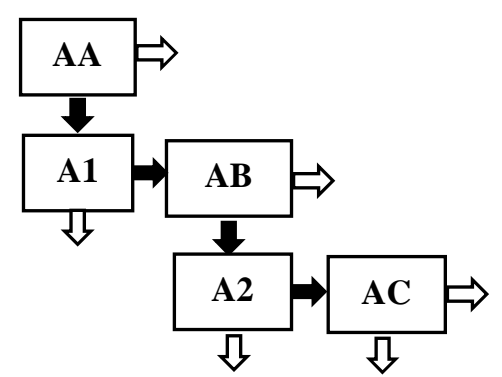

Gambar 1. Bagan Hasil Berpikir Lateral Responden 1 (SL1) Pada Masalah 1

Gambar 1 menunjukkan bahwa SL1 mampu berpikir lateral ditandai dengan adanya perubahan persepsi sebanyak 2 kali pada masalah ini.

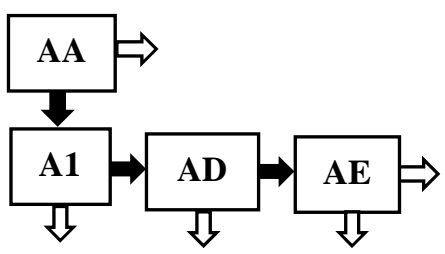

Gambar 2. Bagan Hasil Berpikir Lateral Responden 1 (SL2) Pada Masalah 1

Gambar 2 menunjukkan bahwa SL2 mampu berpikir lateral ditandai dengan adanya perubahan persepsi sebanyak 2 kali pada masalah ini. 


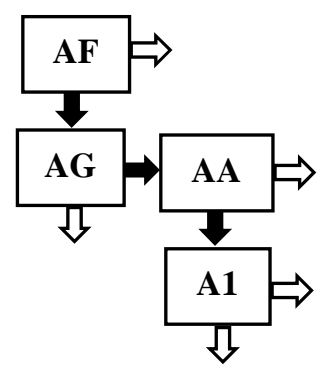

Gambar 3. Bagan Hasil Berpikir Lateral Responden 3 (SL3) Pada Masalah 1

Gambar 3 menunjukkan bahwa SL3 mampu berpikir lateral ditandai dengan adanya perubahan persepsi sebanyak 1 kali pada masalah ini.

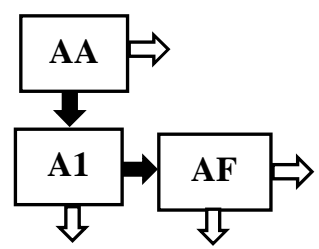

Gambar 4. Bagan Hasil Berpikir Lateral Responden 4 (SL4) Pada Masalah 1

Gambar 4 menunjukkan bahwa SL4 mampu berpikir lateral ditandai dengan adanya perubahan persepsi sebanyak 1 kali pada masalah ini.

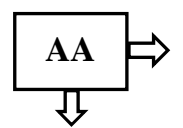

Gambar 5. Bagan Hasil Berpikir Lateral Responden

\section{5 (SL5) Pada Masalah 1}

Gambar 5 menunjukkan bahwa SL5 tidak mampu berpikir lateral ditandai dengan tidak adanya adanya perubahan persepsi sebanyak 1 kali pada masalah ini.

Untuk SL6 tabel pola yang diperoleh sama seperti pada gambar 4, sehingga dapat dikatakan bahwa SL6 berpikir lateral ditandai dengan adanya perubahan persepsi pada msalah ini. Sedangkang untuk SL7 dan SL8 pola yang diperoleh seperti yang ditunjukkan pada gambar 5 , jadi dapat dikatakan bahwa SL7 dan SL8 tidak dapat berpikir lateral pada masalah ini karena tidak adanya perubahan persepsi.

\section{MASALAH 2}

Berikut ini pola jawaban responden untuk masalah 2.

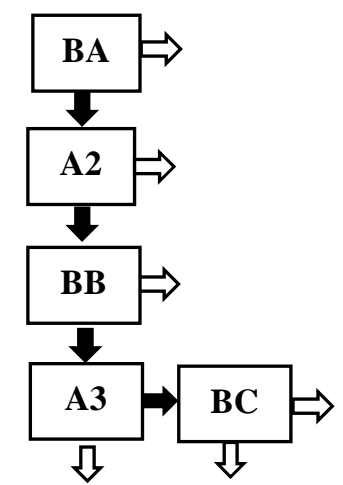

Gambar 6. Bagan Hasil Berpikir Lateral Responden 1 (SL1) Pada Masalah 2

Gambar 6 menunjukkan bahwa SL1 mampu berpikir lateral ditandai dengan adanya perubahan persepsi sebanyak 1 kali pada masalah ini.

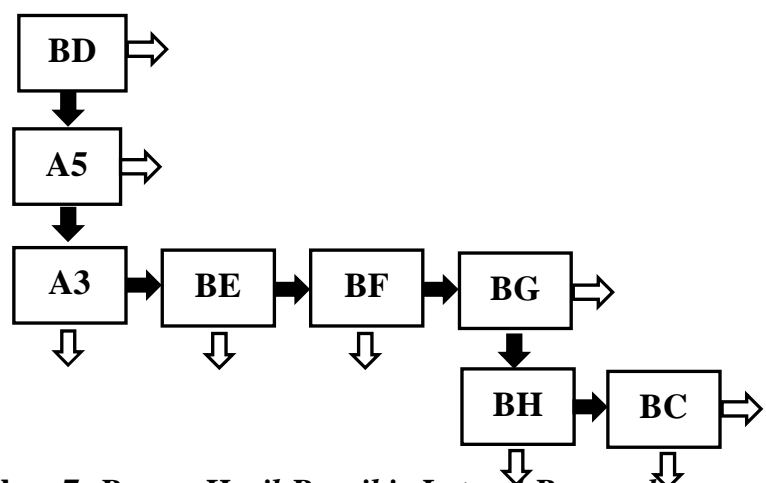

Gambar 7. Bagan Hasil Berpikir Lateră Respondên 2 (SL2) Pada Masalah 2

Gambar 7 menunjukkan bahwa SL2 mampu berpikir lateral ditandai dengan adanya perubahan persepsi sebanyak 4 kali pada masalah ini. 


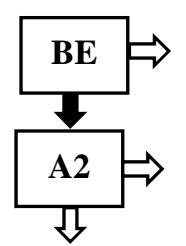

Gambar 8. Bagan Hasil Berpikir Lateral Responden 4 (SL4) Pada Masalah 2

Gambar 8 menunjukkan bahwa SL4 tidak mampu berpikir lateral ditandai dengan tidak adanya perubahan persepsi pada masalah ini.

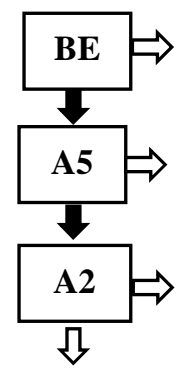

Gambar 9. Bagan Hasil Berpikir Lateral Responden 5 (SL5) Pada Masalah 2

Gambar 9 menunjukkan bahwa SL5 tidak mampu berpikir lateral ditandai dengan tidak adanya perubahan persepsi pada masalah ini.

Untuk SL3 tabel pola yang diperoleh sama seperti pada gambar 1, sehingga dapat dikatakan bahwa SL3 berpikir lateral ditandai dengan adanya perubahan persepsi pada masalah ini. Untuk SL6 pola yang diperoleh seperti yang ditunjukkan pada gambar 5, jadi dapat dikatakan bahwa SL6 tidak dapat berpikir lateral pada masalah ini karena tidak adanya perubahan persepsi Sedangkang untuk SL7 dan SL8 pola yang diperoleh seperti yang ditunjukkan pada gambar 5, jadi dapat dikatakan bahwa SL7 dan SL8 dapat berpikir lateral pada masalah ini karena adanya perubahan persepsi terhadap jawaban yang diberikan.

\section{MASALAH 3}

Berikut ini pola jawaban responden untuk masalah 3.

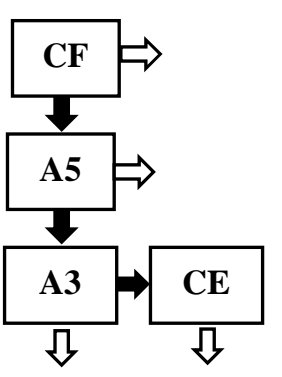

Gambar 10. Bagan Hasil Berpikir Lateral Responden 3 (SL3) Pada Masalah 3

Gambar 10 menunjukkan bahwa SL3 mampu berpikir lateral ditandai dengan adanya perubahan persepsi sebanyak 1 kali pada masalah ini.

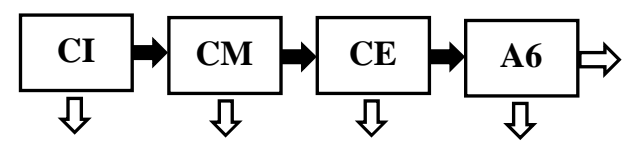

Gambar 11. Bagan Hasil Berpikir Lateral Responden 6 (SL6) Pada Masalah 3

Gambar 11 menunjukkan bahwa SL6 mampu berpikir lateral ditandai dengan adanya perubahan persepsi sebanyak 3 kali pada masalah ini.

Untuk SL1, SL2, SL4 dan SL6 tabel pola yang diperoleh masing-masing sama seperti pada gambar 1, gambar 6, gambar 4 dan gambar 2, sehingga dapat dikatakan bahwa SL1, SL2, SL4 dan SL5 dapat berpikir lateral ditandai dengan adanya perubahan persepsi pada masalah ini. Sedangkang untuk SL7 dan SL8 pola yang diperoleh seperti yang ditunjukkan pada gambar 5, jadi dapat dikatakan bahwa SL7 dan SL8 tidak dapat berpikir lateral pada masalah ini karena tidak adanya perubahan persepsi terhadap jawaban yang diberikan.

\section{MASALAH 4}

Berikut ini pola jawaban responden untuk masalah 4. 


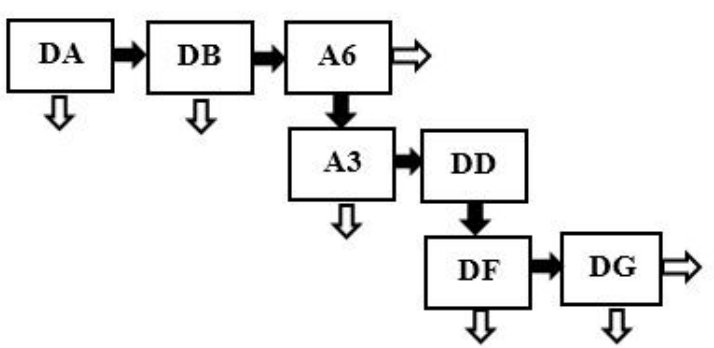

Gambar 12. Bagan Hasil Berpikir Lateral Responden 1 (SL1) Pada Masalah 4.

Gambar 13 menunjukkan bahwa SL1 mampu berpikir lateral ditandai dengan adanya perubahan persepsi sebanyak 3 kali pada masalah ini.

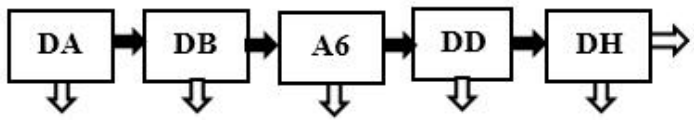

Gambar 13. Bagan Hasil Berpikir Lateral Responden 2 (SL2) Pada Masalah 4.

Gambar 14 menunjukkan bahwa SL2 mampu berpikir lateral ditandai dengan adanya perubahan persepsi sebanyak 4 kali pada masalah ini.

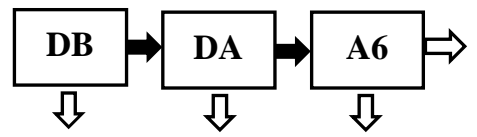

Gambar 14. Bagan Hasil Berpikir Lateral Responden 4 (SL4) Pada Masalah 4.

Gambar 14 menunjukkan bahwa SL4 mampu berpikir lateral ditandai dengan adanya perubahan persepsi sebanyak 2 kali pada masalah ini.

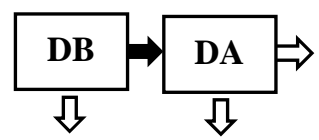

Gambar 15. Bagan Hasil Berpikir Lateral Responden 6 (SL6) Pada Masalah 4.
Gambar 15 menunjukkan bahwa SL6 mampu berpikir lateral ditandai dengan adanya perubahan persepsi sebanyak 1 kali pada masalah ini.

Untuk SL3, SL5, SL7 dan SL8 tabel pola yang diperoleh masing-masing sama seperti pada gambar 9, gambar 13, dan gambar 14, sehingga dapat dikatakan bahwa SL3, SL5, SL7 dan SL8 dapat berpikir lateral ditandai dengan adanya perubahan persepsi pada masalah ini.

\section{MASALAH 5}

Untuk SL1 dan SL2, SL5, dan SL7 tabel pola yang diperoleh masing-masing sama seperti pada gambar 1, gambar 9 dan gambar 13, sehingga dapat dikatakan bahwa SL1, SL2, SL5 dan SL7 dapat berpikir lateral ditandai dengan adanya perubahan persepsi pada masalah ini. Sedangkang untuk SL4 dan SL8 pola yang diperoleh seperti yang ditunjukkan pada gambar 5, jadi dapat dikatakan bahwa SL4 dan SL8 tidak dapat berpikir lateral pada masalah ini karena tidak adanya perubahan persepsi terhadap jawaban yang diberikan

\section{MASALAH 6}

Berikut ini pola jawaban responden untuk masalah 6.

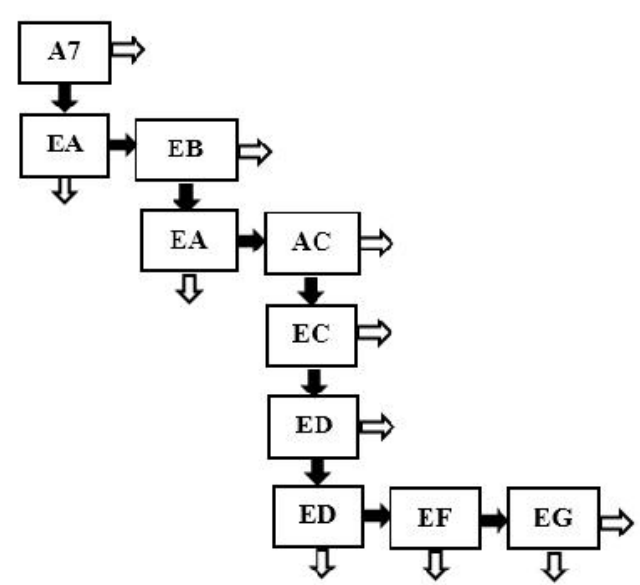

Gambar 16. Bagan Hasil Berpikir Lateral Responden 1 (SL1) Pada Masalah 6. 
Gambar 16 menunjukkan bahwa SL1 mampu berpikir lateral ditandai dengan adanya perubahan persepsi sebanyak 4 kali pada masalah ini.

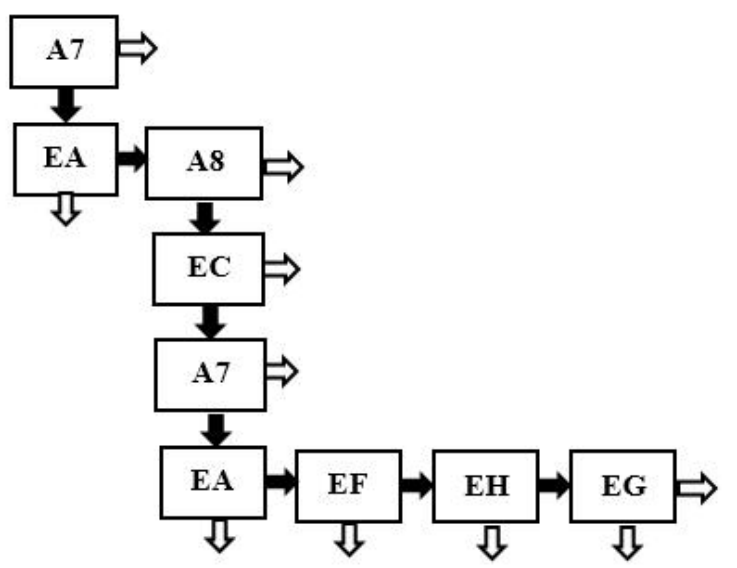

Gambar 17. Bagan Hasil Berpikir Lateral Responden 2 (SL2) Pada Masalah 6.

Gambar 17 menunjukkan bahwa SL2 mampu berpikir lateral ditandai dengan adanya perubahan persepsi sebanyak 4 kali pada masalah ini.

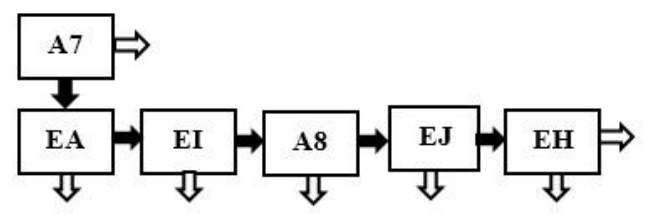

Gambar 18. Bagan Hasil Berpikir Lateral Responden 4 (SL4) Pada Masalah 6.

Gambar 18 menunjukkan bahwa SL4 mampu berpikir lateral ditandai dengan adanya perubahan persepsi sebanyak 4 kali pada masalah ini.

Untuk SL3, SL6 dan SL7 tabel pola yang diperoleh sama seperti pada gambar 4, sehingga dapat dikatakan bahwa SL3, SL6, dan SL7 dapat berpikir lateral ditandai dengan adanya perubahan persepsi pada masalah ini. Sedangkang untuk SL5 dan SL8 pola yang diperoleh seperti yang ditunjukkan pada gambar 5, jadi dapat dikatakan bahwa SL7 dan SL8 tidak dapat berpikir lateral pada masalah ini karena adanya perubahan persepsi terhadap jawaban yang diberikan.

\section{MASALAH 7}

Berikut ini pola jawaban responden untuk masalah 7.

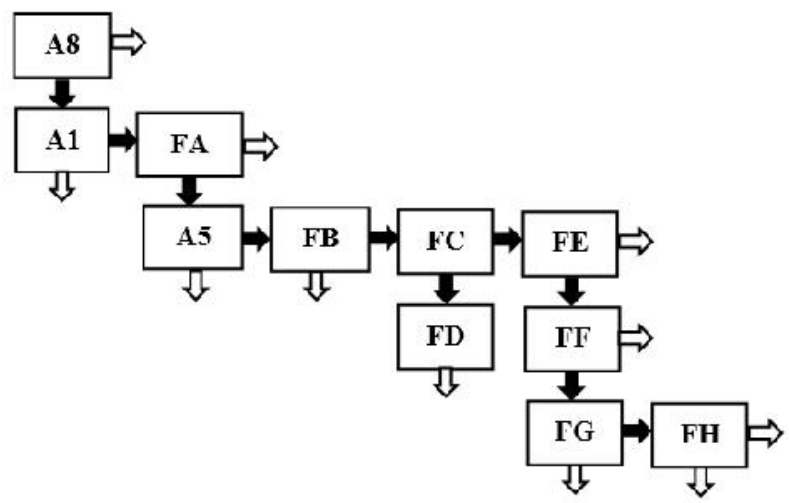

Gambar 19. Bagan Hasil Berpikir Lateral Responden 1 (SL1) Pada Masalah 7.

Gambar 19 menunjukkan bahwa SL1 mampu berpikir lateral ditandai dengan adanya perubahan persepsi sebanyak 4 kali pada masalah ini.

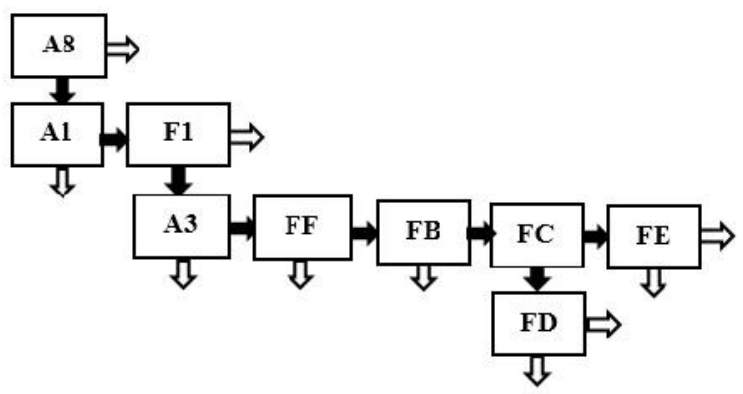

Gambar 20. Bagan Hasil Berpikir Lateral Responden 2 (SL2) Pada Masalah 7.

Gambar 20 menunjukkan bahwa SL2 mampu berpikir lateral ditandai dengan adanya perubahan persepsi sebanyak 3 kali pada masalah ini.

Untuk SL3, SL5, SL6, SL7 dan SL8 tabel pola yang diperoleh sama seperti pada gambar 4, sehingga dapat dikatakan bahwa SL3, SL5, SL6, SL7 dan SL8 dapat berpikir lateral ditandai 
dengan adanya perubahan persepsi pada masalah ini. Sedangkang untuk SL4 pola yang diperoleh seperti yang ditunjukkan pada gambar 12 , jadi dapat dikatakan bahwa SL4 dapat berpikir lateral pada masalah ini karena tidak adanya perubahan persepsi terhadap jawaban yang diberikan.

\section{MASALAH 8}

Pada masalah 8, untuk SL1 dan SL2 tabel pola yang diperoleh masing-masing sama seperti pada gambar 10 dan gambar 4, sehingga dapat dikatakan bahwa SL1 dan SL2 dapat berpikir lateral ditandai dengan adanya perubahan persepsi pada masalah ini. Sedangkang untuk SL3, SL4, SL5, SL6, SL7 dan SL8 pola yang diperoleh seperti yang ditunjukkan pada gambar 5, jadi dapat dikatakan bahwa kelima responden tersebut tidak dapat berpikir lateral pada masalah ini karena tidak adanya perubahan persepsi terhadap jawaban yang diberikan.tidak memberikan tanggapan balik atau cara lain terhadap masalah ini.

Berdasarkan urain di atas, dapat dilihat bahwa ada beberapa responden yang sudah mampu berpikir lateral pada masalah yang diberikan dan ada peserta didik yang tidak mampu berpikir lateral pada masalah yang diberikan seperti pada masalah 8 , dari 8 responden hanya 2 responden saja yang mampu berpikir lateral pada masalah tersebut dan untuk responden lainnya masuk dalam kategori tidak mampu berpikir lateral. Namun jika ditinjau dari semua masalah yang diberikan kepada setiap responden dapat dikatakan bahwa responden tersebut sudah mampu berpikir lateral. Hal ini terjadi dikarenakan masih rendahnya pemahaman peserta didik mengenai konsep fisika dan kurangnya kemauan peserta didik untuk mencari tahu lebih lanjut tentang masalah yang diberikan. Sehingga sangat perlu untuk selalu memberikan soal-soal bersifat lateral kepada peserta didik untuk merangsang proses berpikir peserta didik.

\section{SIMPULAN}

Berdasarkan fokus penelitian dan hasil penelitian terhadap kemampuan berpikir lateral peserta didik maka dapat disimpulkan bahwa pada umumnya peserta didik sudah mampu berpikir lateral dalam memecahkan masalah fisika yang ditandai dengan adanya perubahan persepsi terhadap masalah yang diberikan

\section{DAFTAR RUJUKAN}

Akhmat, Hidayatno. 2013. Berpikir Sistem Pola Berpikir Untuk Memahami Masalah yang Lebih Baik. Jakarta: Universitas Indonesia.

Anonim. 2018. Analisis Kemampuan Berpikir Lateral Siswa dalam Menyelesaikan Soal Cerita Pada Materi Permutasi. Jambi: FKIP Universitas Jambi.

De Bono, E. 1971. Lateral thinking for management; a handbook of creativity. New York,:American Management Association.

De Bono, E. 1994. De Bono's thinking course. New York: Facts On File.

Depdiknas. 2006. Permendiknas No.22 Tahun 2006 Tentang Standar Isi. Jakarta: Depdiknas.

Gregory, RJ. 2014. Psychologi Testing History, Principle, and Aplications Seven Edition. New York: Facts On File.

Jabir, jayanti. 2018. Kemampuan Berpikir Lateral Peserta Didik Dalam Menyelesaikan Masalah Fisika di MAN Luwu. makassar: Universitas Negeri Makassar. 
84 Jurnal Sains dan Pendidikan Fisika. Jilid 15, Nomor 2, Agustus 2019, hal. 76-84

N Priatna. 2018. Developing Geogebra-assisted

Reciprocal Teaching Strategy to

Improve Junior High School Students

Abstraction Ability, Lateral Thinking And

Mathematical Presistence. IOP conf.

Series: Journal of Physics 1013

(2018) 012142.

Sugiono. 2011. Metode Penelitian Kuantitatif, Kualitatif, dan $R \& B$. Bandung: Alfabeta.

Sugiono. 2013. Memahami Penelitian

Kualitatif. Bandung: Alfabeta. 